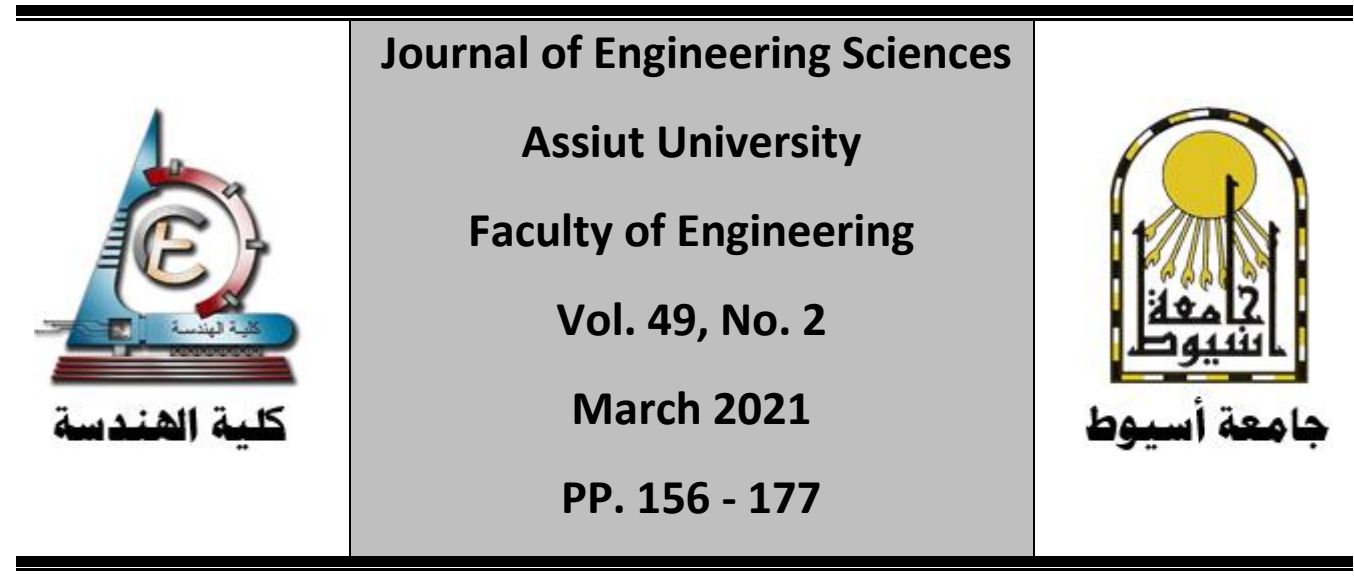

\title{
Cost Benefit Analysis of Applying Thermal Insulation Alternatives to Saudi Residential Buildings
}

\section{Nedhal Al-Tamimi}

Architectural Engineering Department, College of Engineering, Najran University naaltamimi@nu.edu.sa

Received 20 November 2020; Revised 17 January 2021; Accepted 07 Feb. 2021

\begin{abstract}
Given the rapidly increasing number of air-conditioned buildings, the electricity demand in the Kingdom of Saudi Arabia has increased during the past decade. Efficient thermal insulation is extremely important for energy efficiency and sustainability, especially with the country's hot-arid climate. This study explores the law of diminishing returns when improving the conservation level of residential buildings by using case study simulation. Specifically, this study aims to identify alternative positions for the insulation material and the optimum thickness for the three proposed strategies (on the roof only, on the walls only and on the roof and walls) in accordance with the energy efficiency index defined in the thermal insulation regulation of the KSA. Moreover, this study uses the life cycle cost model to manage the optimum number of insulation levels. This study also uses DesignBuilder energy simulation tool to estimate the energy performance and the environmental impact of a sample prototype villa with a gross area of $238 \mathrm{~m}^{2}$ in Najran City. The optimum insulation thickness is defined based on the cost benefits of the extruded polystyrene material (XPS) over its lifetime. Results show that the optimum insulation thicknesses of 8,4 and $6 \mathrm{~cm}$ must be applied on the roof only, the walls only and the roof and walls. These
\end{abstract}


alternatives can lead to reductions of $19.14 \%, 7.51 \%$ and $29.77 \%$ on annual energy consumption, respectively. A substantial reduction on $\mathrm{CO}_{2}$ emission is also achieved. Finally, the payback period in the three optimum alternatives are $3.73,12.14$ and 6.39 years, respectively.

Keywords: Building thermal insulation; A/C energy consumption; Building life cycle cost; Cost-benefit analysis; DesignBuilder.

\section{Introduction}

The Kingdom of Saudi Arabia (KSA) is one of the fastest-growing countries in the world, with a population of 34.2 million, an area of 2 million $\mathrm{km}^{2}$, a density of 15.3 inhabitants per $\mathrm{km}^{2}$ and a population growth rate of $2.1 \%[1,2]$. KSA also has an annual economic growth rate of $6.8 \%$. The annual primary energy consumption in the country has increased abruptly in the past years from approximately 3.88 MWh/capita in 1980 to $9.14 \mathrm{MWh} /$ capita in 2014 [3, 4]. Given the country's hot arid climate, the rapid development and urbanisation of the construction industry have contributed to the national total electricity demand of $77 \mathrm{GW}$ and the total desalinated water demand of 1,912 million $\mathrm{m}^{3}$ in 2014 [1, 4]. However, the concept of energy efficiency is not seriously considered in Saudi building designs compared with other countries [5].

As shown in Figs. 1 and 2, the residential sector consumes half of the total generated electricity, of which $70 \%$ is attributed to air conditioning (A/C) systems. This situation is evident in all Saudi operating districts. For instance, the total energy consumption in the Southern Operating District has reached a maximum of $67 \%$ [4]. Energy consumption in buildings in many countries is largely attributed to $\mathrm{A} / \mathrm{C}$, and the daily energy demand to cool buildings is continuously growing, especially in those with hot arid climates. Proper management of this energy requirement can reduce fuel usage for electricity generation and $\mathrm{CO}_{2}$ emissions while maintaining the indoor air quality inside buildings and the thermal comfort of buildings' occupants. Insulating building envelope is considered one of the best strategies to control the heat flow through its components. This method can be utilised to reduce energy consumption for space cooling and heating. However, the cost of the insulation material increases linearly with its thickness $[6,7]$. Therefore, finding the optimum point wherein the total 
investment cost for the insulation thickness and energy consumption can be minimised is helpful in reducing the operation and construction costs.

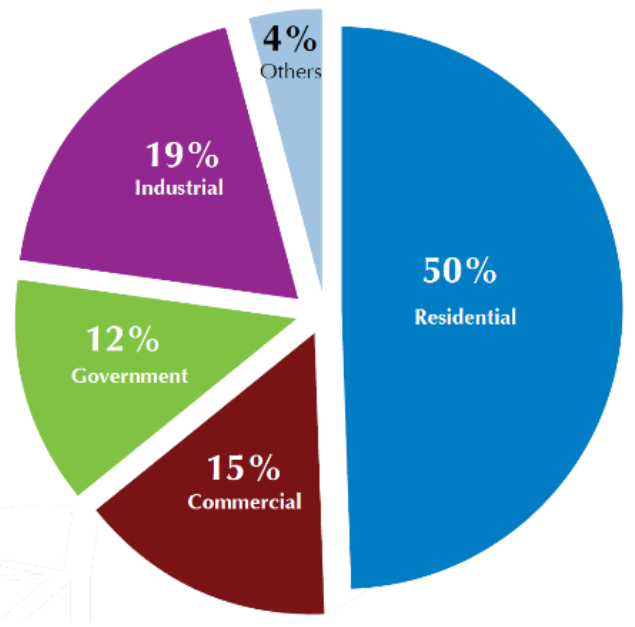

Fig. 1. Distribution of consumption by class-kingdom-wise

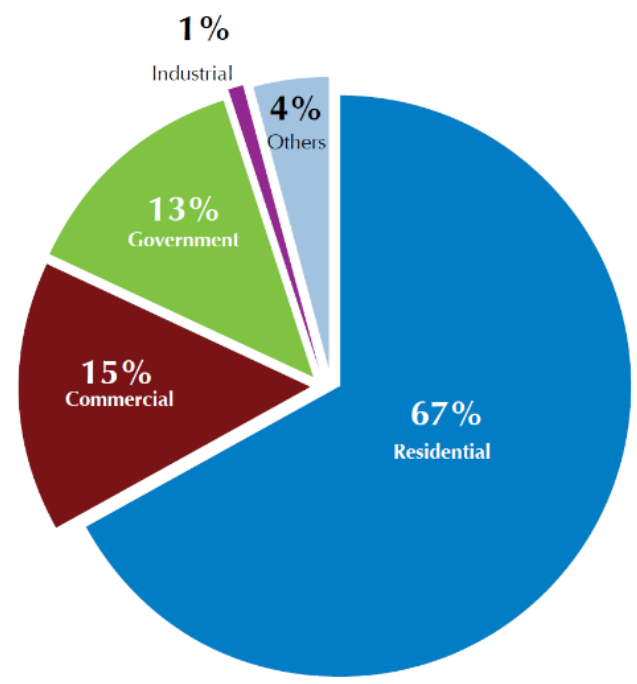

Fig. 2. Distribution of consumption in the Southern Operating District

Inefficient design and operation of many buildings in KSA lead to the overall poor thermal performance of building envelopes [8]. For instance, approximately $70 \%$ of existing residential buildings are not thermally insulated [9]. The rigorous desert climate of KSA and huge energy use in hot summer must be considered in determining the optimum insulation thickness. This study explores the law of diminishing returns when improving the conservation level of residential buildings by using case study simulation. Specifically, it proposes the application of three insulation systems with different insulation thicknesses on the roof only, walls only and roof and walls of a typical Saudi villa to determine the optimum solution based on cost benefit analysis. In general, the optimisation of insulation thickness in residential building envelopes in Najran City is based on three major steps: determining the annual energy consumption, identifying the environmental impact in terms of $\mathrm{CO}_{2}$ emission, and conducting an economic analysis. This study is limited to the new low-rise construction of Saudi residential buildings. The thermal insulation materials investigated in this study are those which exist in the Saudi markets. The cost-benefit is also limited to the cost of insulation material only. The walls and roofs configurations are those which are 
mostly used by the Saudi constructors. Therefore, the contribution of this work is merely related to the fact that there have not been similar studies on the specific climate, and this work provides a more general methodological framework for the relevant problem.

\section{Related Studies}

Studies related to the optimisation of insulation thickness in building envelopes have been increasing in recent years. Most studies have concluded that applying thermal insulation under optimised conditions is an effective way to conserve energy [10-18]. Others have used degree-day calculation methods and life cycle cost analysis to calculate the optimum insulation thickness of walls from different aspects. However, different results are obtained because of varying study places and climate zone characteristics.

Aldossary et al. [19] analysed energy consumption patterns in the hot and humid climate of Jeddah, KSA. They explored three typical detached houses and three typical apartment units by using IES-VE program and conducted energy simulation to reduce energy consumption. Their results indicate that the average energy consumption of Saudi residential buildings is $185.4 \mathrm{kWh} / \mathrm{m}^{2} / \mathrm{y}$. They concluded that the high energy consumption is due to the lack of thermal insulation. A study [20] showed that the insulation of external walls and roofs increase energy conservation by up to $77 \%$. Another study [14] investigated the optimum insulation thickness for external wall in three coldest cities of Turkey. They based their optimisation on life cycle cost analysis and applied optimum insulation thickness that resulted in an energy saving of $12.113 \$ / \mathrm{m}^{2}$. Like Turkey, ambient temperatures and solar radiation levels in Sub-Saharan Africa are sufficiently high that buildings do not need energy for heating even during winter. Thus, roof insulation is as important as that of wall. The optimum insulation thicknesses in buildings in Turkey vary between 1.06 and $7.64 \mathrm{~cm}$, and the energy conservation varies between 19 and $47 \$ / \mathrm{m}^{2}$ [21]. Daouas et al. [22] found that the most profitable case for insulation is the stone/brick sandwich wall and expanded polystyrene (XPS), with an optimum thickness of $5.7 \mathrm{~cm}$. Their proposed method has achieved energy conservation up to $58 \%$ with a payback period of 3 years. 
Alrashed F. and Asif M. [23] investigated some factors related to residential energy consumption, such as weather conditions, types of dwellings, building envelops and A/C systems. They based their analysis on the actual monthly electricity consumption for 115 dwellings, including 62 apartments, 28 villas and 25 traditional houses, in Dhahran City, Eastern Province of KSA for 2012. They showed that $50 \%$ and more than $75 \%$ of the surveyed apartments and traditional houses are not thermally insulated, respectively. They also found that dwellings with thermal insulation had approximately $32 \%$ lower average electricity consumption than those without thermal insulation. Another study [24] conducted a comparative study on optimum insulation thickness of walls and energy conservation in two cities in equatorial and tropical climates of Cameroon. They based their optimisation on an economic model and conducted a life cycle cost analysis (assumed 22 years) by using one type of insulation material (XPS) and two typical wall structures. Their results show that the optimum insulation thickness of 8 and $11 \mathrm{~cm}$ results in energy conservation of 51.69 and $97.82 \$ / \mathrm{m}^{2}$ in regions with equatorial and tropical climates, respectively. Ekici et al. [25] calculated optimum insulation thickness, energy savings and payback periods for stone, concrete and brick walls by using degree-days of four cities from different climate zones in Turkey. They investigated different energy sources and insulation materials and showed that the optimum insulation thickness varies between 0.2 and $18.6 \mathrm{~cm}$, the payback periods vary between 0.7 and 9.1 years and the energy saving increase up to $250 \$ / \mathrm{m}^{2}$. Bolatturk [26] used heating degree-days concept to estimate the annual heating load of a wall and calculated the optimum insulation thickness by employing different climate zones in Turkey for different fuel types. The results show that the insulation thickness varies between 2 and $17 \mathrm{~cm}$, the energy conservation varies between $22 \%$ and $79 \%$ and the payback period varies between 1.3 and 4.5 years. $\mathrm{Yu}$ et al. [7] studied optimum insulation thickness of residential roofs with different surface colours by using life cycle cost analysis and solar-air degree-hours in four typical cities in hot summer and cold winter zones of China.

According to the 2018 data provided by GAStat [2], the total number of housing units in KSA residential building stock has reached 5,466,910 units in varied categories as illustrated in Fig. 3. Moreover, the number of the licenses being issued for residential units has increased from 
43,733 in 1995 to 313,623 in 2018. Despite the role of insulating solid components of building envelope in energy conservation, most studies have focused on the effect of insulated walls in residential and office buildings. Only few have focused on the optimum insulation thickness of roof or the whole building envelope. The number of multi-storey buildings is limited in KSA. Most buildings are only one to three storeys, whether they are villas or apartments. The heat seeps mainly through the roof because of the turns and the country's location. The sun's verticality is concentrated mainly in the summer, and the temperature exceeds 40 degrees when the sun is perpendicular. This condition increases heat gain, cooling loads, and energy consumption. In summary, a growing interest is observed in the application of thermal and life cycle cost analyses in determining the optimum insulation thickness of building walls under various climatic conditions.

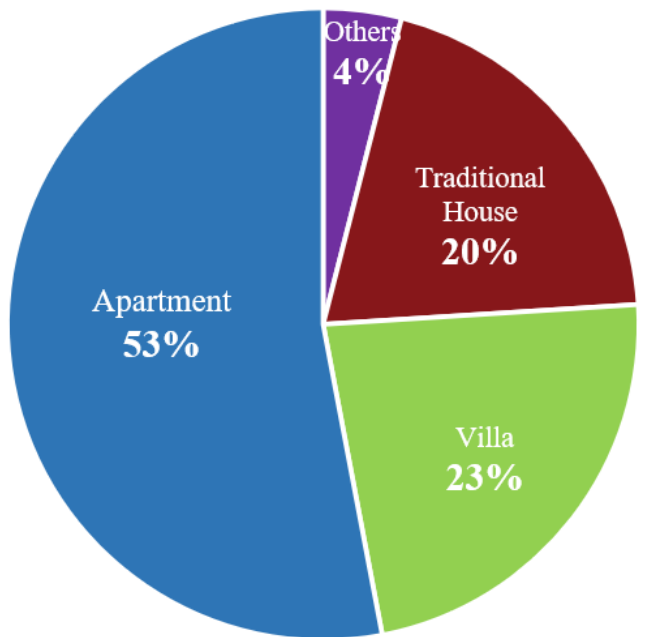

Fig. 3. Distribution of KSA residential buildings.

This study aims to use a systematic simulation method to determine the most economic (optimum) insulation layer of typical villa in the hot arid climate of KSA by employing values of economic parameters pertinent to local conditions and market cost. This work contributes to the best practices of thermal insulation utilisation in residential building envelopes in the country. Although thermal insulation has already been practiced in the past two decades in KSA, the optimum type, thickness and position of the thermal insulation and its impact on energy conservation are still questionable. Najran is selected as the main investigation field city in this study because of its characteristics as 
follows. This city has never been studied before. It represents similar climate to most cities in Saudi and Gulf countries: hot and dry with desert subzone. In this sense, the study could be a design template for other residential buildings with similar climate areas in these countries.

\section{Methodology}

\subsection{Climatic conditions of Najran, KSA}

Najran is in the southwest of KSA and near the Saudi Arabian-Yemeni border as shown in Fig.4. The city lies at the intersection of $17^{\circ} 29^{\prime} \mathrm{N}$ and $44^{\circ} 7^{\prime} \mathrm{E}$, and its latitude is $1,310 \mathrm{~m}$ above sea level. According to the Saudi meteorological authority [27], Najran has a semi-desert climate and receives a minimum of $0 \mathrm{~mm}$ and an average of $7 \mathrm{~mm}$ rainfall in June and April, respectively. The average annual temperature ranges between $18.5{ }^{\circ} \mathrm{C}$ and $33.2{ }^{\circ} \mathrm{C}$ in January and July, respectively. Fig. 5 shows the maximum, minimum and average dry-bulb temperature; total rainfall; wind speed; global solar radiation; and average relative humidity of the city [28].
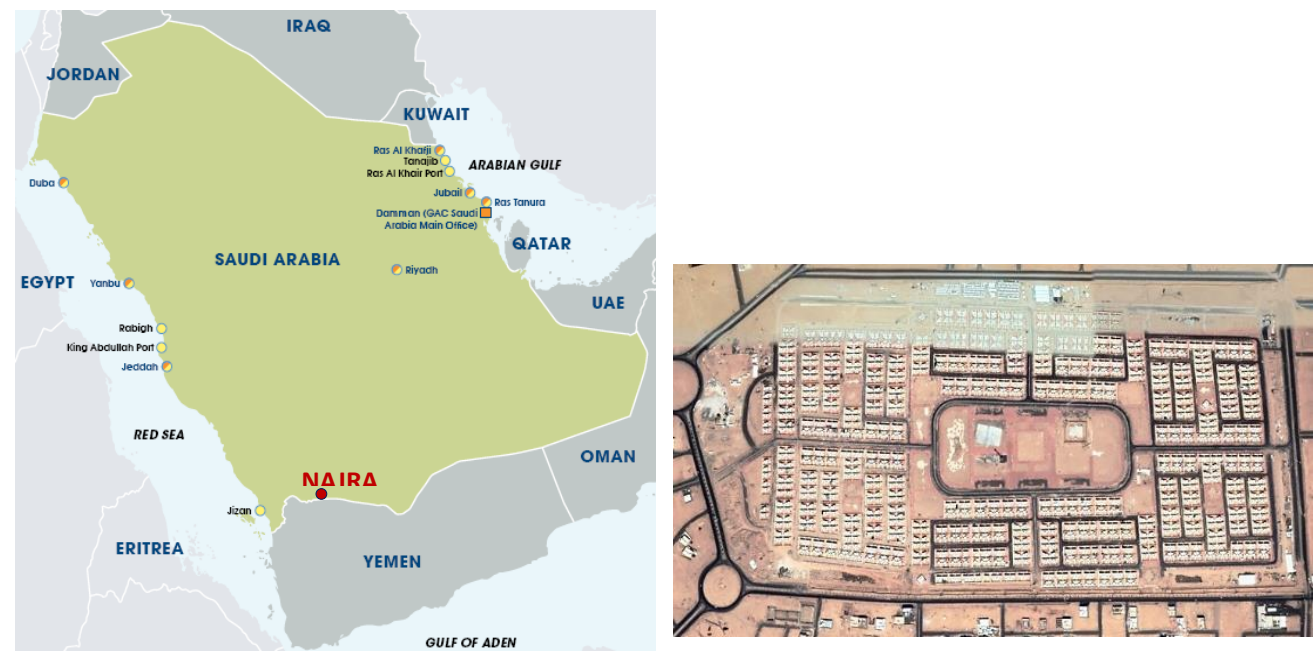

Fig. 4 Map of Saudi Arabia and the location of the case study (Google Earth 2020) 


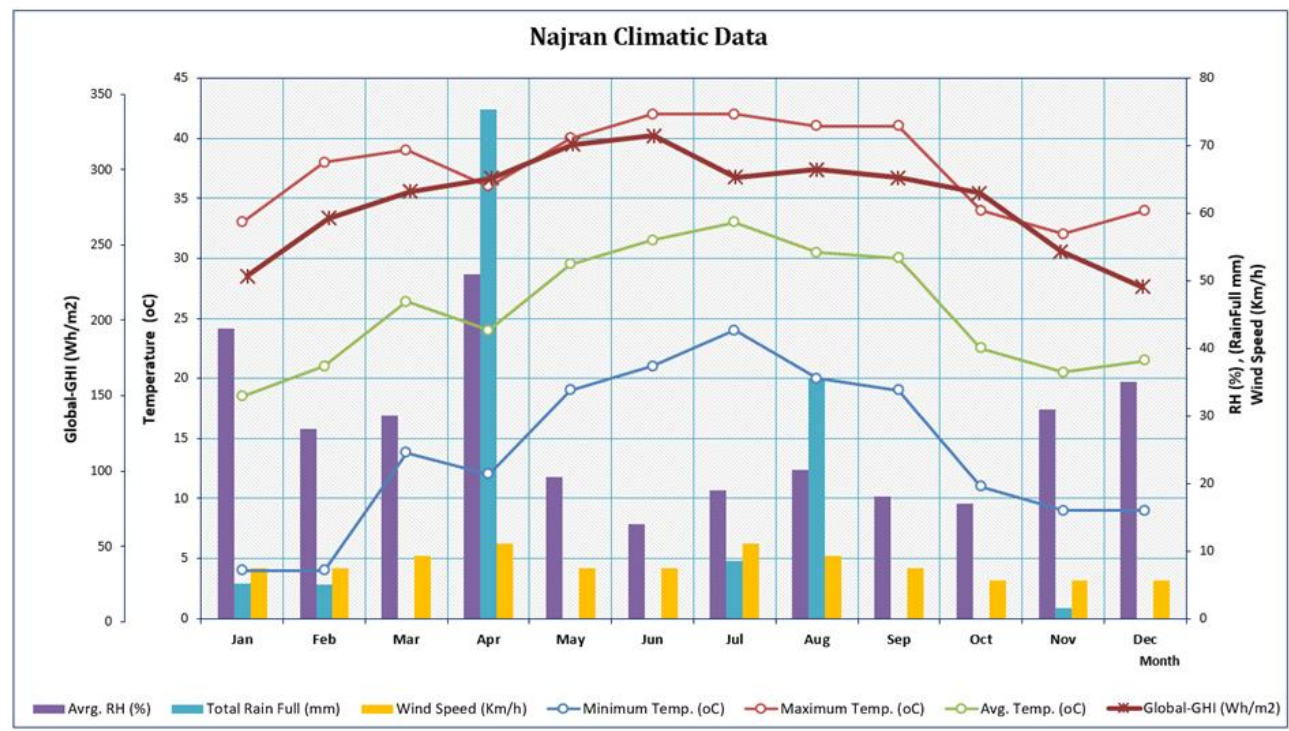

Fig. 5. Najran climatic data [2]

\subsection{Building characteristics}

The residential building considered in this study is a detached family house (villa). This prototype villa is developed by the housing authority of KSA under the name of 'Model A', which has a total of more than 12,000 units in 35 cities all over the kingdom [29]. Given that this model is a standard floor plan for various housing estates developed by the Saudi Housing Authority, it has no fixed location or orientation. The data about this typical building are obtained from two sources: (i) review of building drawings approved by the housing authority and (ii) site visits to the housing campus in the city. The obtained data include information related to building systems (types and operation), schedules of occupancy and house appliances. The case study building comprises two storeys, with a built floor area of $238 \mathrm{~m}^{2}$ and a total land area of $500 \mathrm{~m}^{2}$. The floor plans and perspectives of the case study are illustrated in Figs. 6 and 7. The material and construction characteristics and the specifications of $\mathrm{A} / \mathrm{C}$ and lighting systems used in this building are summarised in Table 1. 

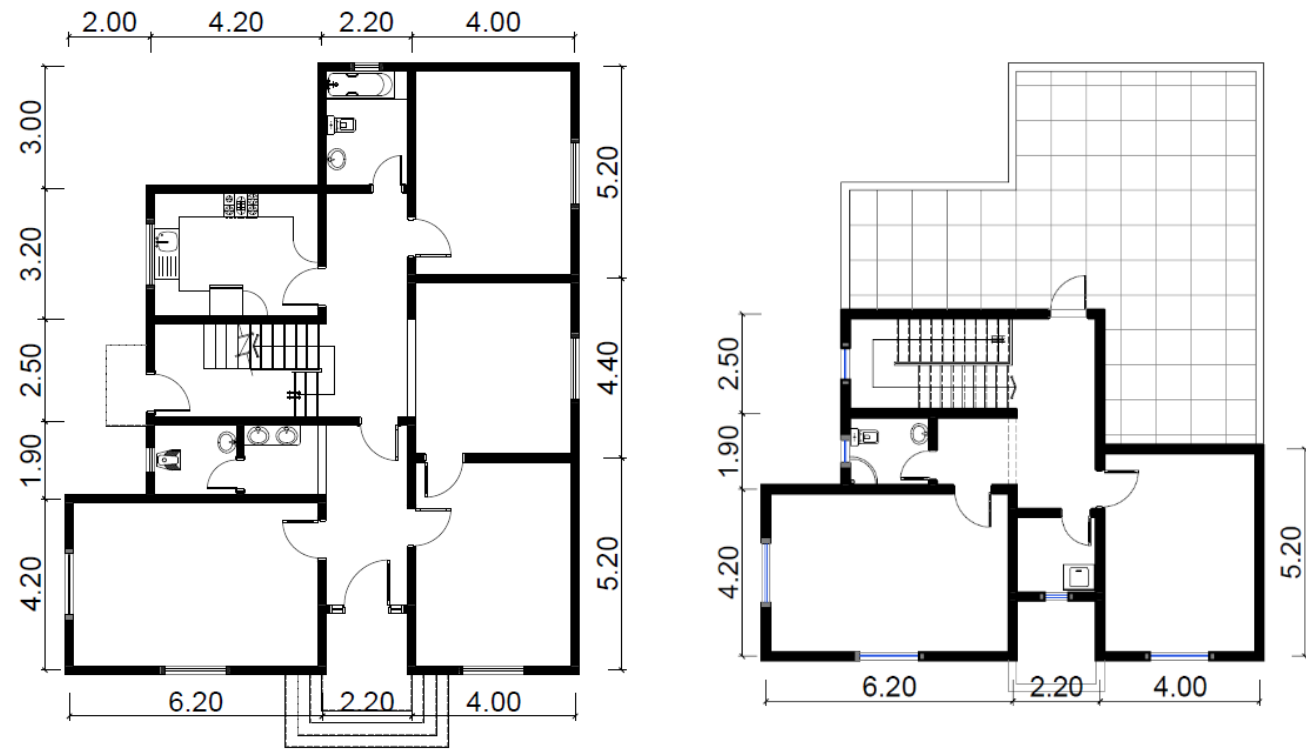

Fig. 6. Ground and first floor plans of the typical villa

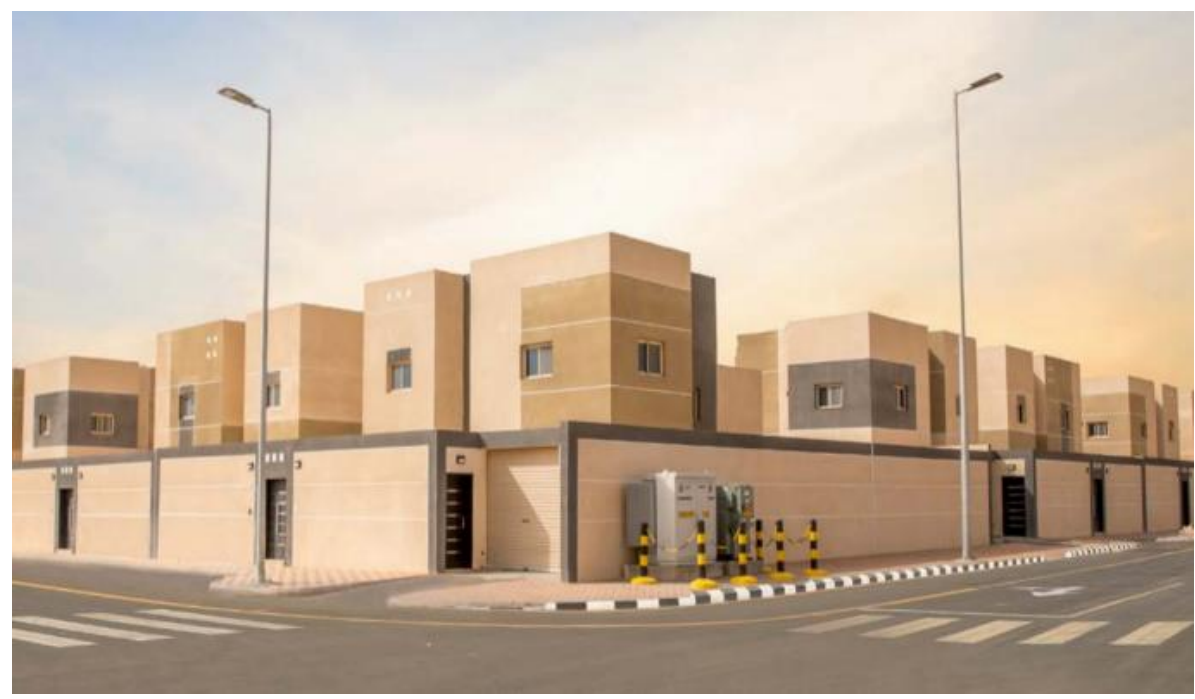

Fig. 7. Perspectives of the typical villa

\subsection{Building simulation}

Computer-based simulation is a technology used to model design and usage changes accurately $[30,31]$. The rendering for the energy models for the prototype is conducted using an hourly building simulation tool called DesignBuilder, as shown in Fig. 8. This software is based on the state-of-the-art building performance simulation software EnergyPlus [32]. Monthly electricity bills for ten villas were collected for the whole year of 2018. For the comparison between the actual electricity 
consumption and the simulated one, the annual consumption was calculated for each villa. The average energy consumption of the ten villas is $182.84 \mathrm{KW} / \mathrm{h} / \mathrm{m}^{2}$. The villa is then simulated under the weather file of Najran city. The energy model is calibrated following the comparison between the monthly energy consumption and the actual consumption from the utility bills, as shown in Fig. 9. After the calibration procedure, the annual energy consumption of the simulated villas is $193.07 \mathrm{KW} / \mathrm{h} / \mathrm{m}^{2}$. The simulated data from the building energy stock model show a good agreement with the actual data with relative errors of approximately $5.3 \%$.

Table 1. Building construction, HVAC, and lighting systems specifications of the case study

\begin{tabular}{ll}
\multicolumn{1}{c}{ Characteristics } & \multicolumn{1}{c}{ Description } \\
\hline Number of floors & $238 \mathrm{~m}^{2}$ \\
\hline Gross floor area & $357 \mathrm{~m}^{2}$ \\
\hline Gross wall area & $140 \mathrm{~m}^{2}$ \\
\hline Gross roof area & $6.1 \%$ \\
\hline Window-to-wall ratio & $20 \mathrm{~mm}$-thick plaster \\
\hline External wall construction & $200 \mathrm{~mm}$-thick concrete blocks \\
(from outside to inside) & $20 \mathrm{~mm}$-thick plaster (light) \\
(U-value: $1.650 \mathrm{~W} / \mathrm{m} 2-K)$ & $20 \mathrm{~mm}$-thick plaster (light) \\
\hline & $150 \mathrm{~mm}$-thick concrete blocks \\
Internal partition construction & $20 \mathrm{~mm}$-thick plaster (light) \\
\hline & $20 \mathrm{~mm}$-thick cemented tiles \\
& $15 \mathrm{~mm}$-thick mortar \\
Roof construction & $50 \mathrm{~mm}$-thick sandstone \\
(from outside to inside) & $150 \mathrm{~mm}$-thick reinforced concrete \\
(U-value: $3.644 \mathrm{~W} / \mathrm{m} 2-K)$ & $13 \mathrm{~mm}$-thick plaster (light) \\
\hline & $12 \mathrm{~mm}$-thick ceramic tiles \\
Ground floor construction & $15 \mathrm{~mm}$-thick mortar \\
& $100 \mathrm{~mm}$-thick light reinforced concrete \\
\hline Type of glass $(U$-value: $5.778 \mathrm{~W} / \mathrm{m} 2-K)$ & $150 \mathrm{~mm}$-thick base-course stone \\
\hline Number of occupants & $6 \mathrm{~mm}$-thick single clear \\
\hline Lighting power density & 6 \\
\hline Appliance power density & $4.0 \mathrm{~W} / \mathrm{m}^{2}$ \\
\hline Cooling set point & $3.5 \mathrm{~W} / \mathrm{m}^{2}$ \\
\hline HVAC system $(C o P: 2.17)$ & $24{ }^{\circ} \mathrm{C}$ \\
\hline & $\mathrm{DX}$ air-cooled A/C system with electric \\
thermostat
\end{tabular}




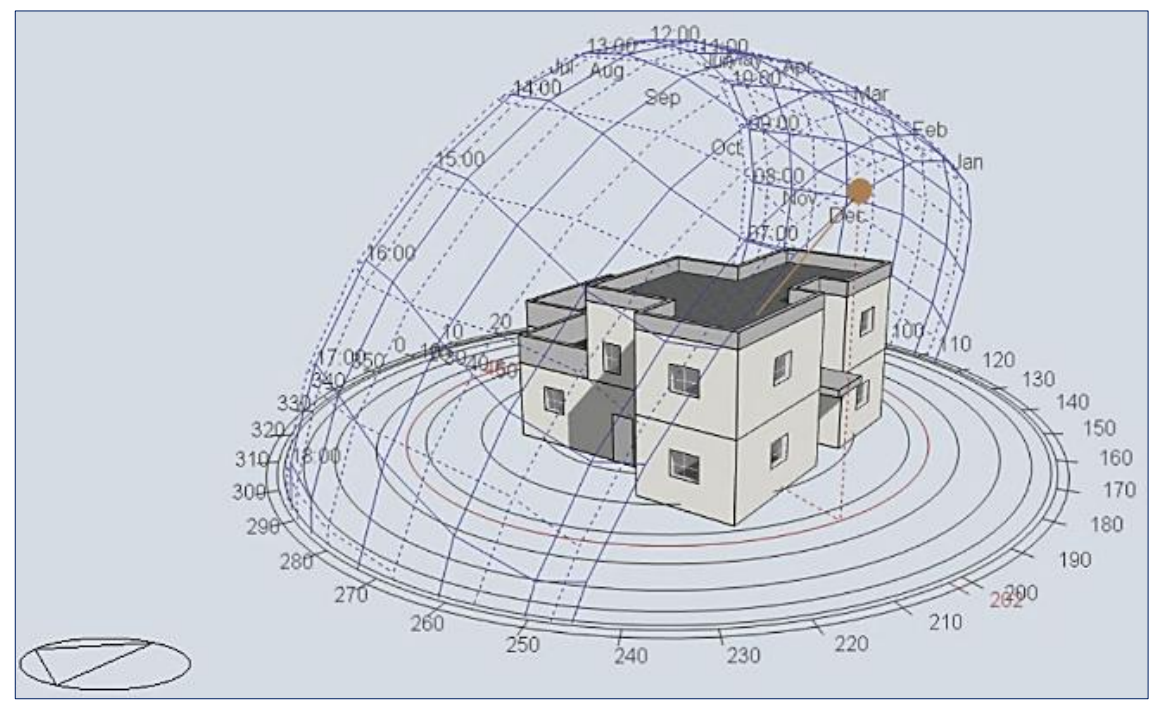

Fig. 8. Rendering for the base case building energy model

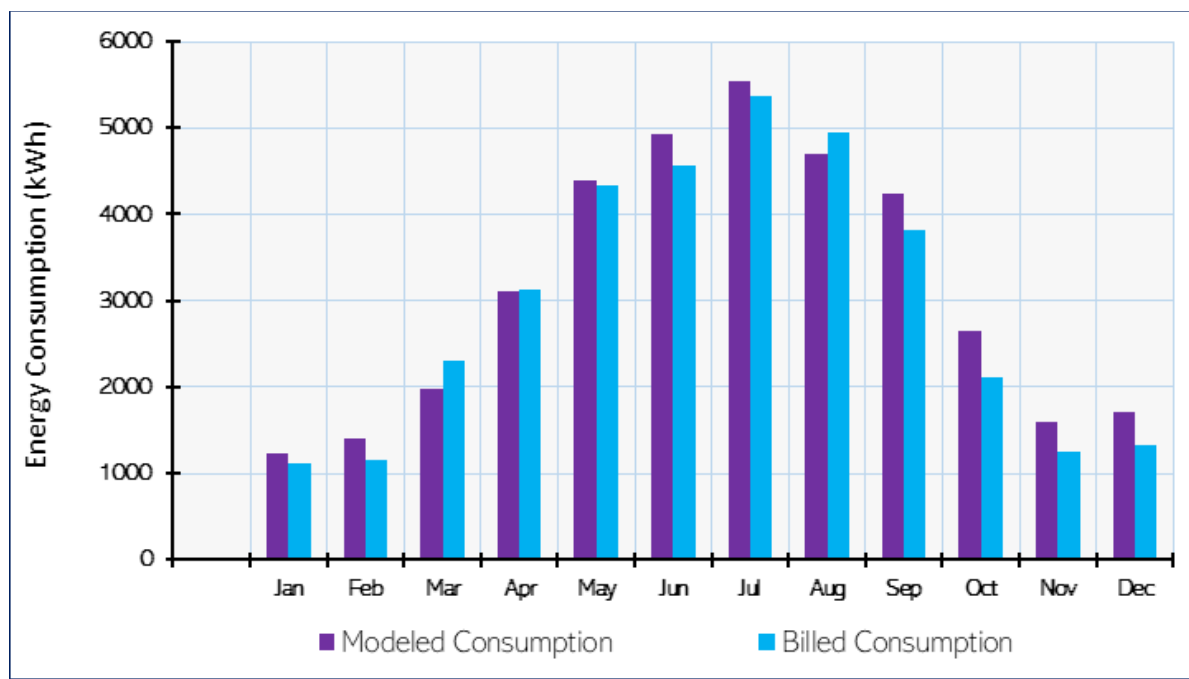

Fig. 9. Comparison between simulation results and billed consumption for the base case

\subsection{Selection criteria of insulation material}

Many parameters, including durability, cost, compressive strength, water vapour absorption and transmission, fire resistance, ease of application and thermal conductivity, must be considered when selecting thermal insulation [33]. However, the thermal transmittance (U-value) and the cost are the most important criteria when considering thermal performance and energy conservation issues. Previous studies in different countries have recommended the use of XPS for future studies, indicating its greater impact on energy saving and cost benefits 
than other types of insulation [7, 10, 16, 34]. Moreover, XPS is used based on its availability, reasonable cost, ease of application and its lower thermal conductivity. The performance characteristics of XPS insulation and other types are shown in Table 2 [35]. The related parameters used in economic analysis of the insulation material and its position in the building construction are provided in Table 3.

Table 2. Performance characteristics of different insulation types

\begin{tabular}{|c|c|c|c|c|}
\hline Insulation type & $\begin{array}{l}\text { XPS (closed } \\
\text { cell foam) }\end{array}$ & Fiberglass & Rockwool & Polyethylene \\
\hline Density $\left(\mathrm{kg} / \mathrm{m}^{3}\right)$ & $26-45$ & $12-56$ & $40-200$ & $35-40$ \\
\hline $\begin{array}{c}\text { Thermal conductivity } \\
(\mathrm{W} / \mathrm{m}-\mathrm{K})\end{array}$ & $0.032-0.030$ & $0.04-0.033$ & 0.037 & 0.041 \\
\hline $\begin{array}{c}\text { Water absorption } \\
(\%)\end{array}$ & $\begin{array}{l}\text { Excellent } \\
(0.2-1.0) \\
\end{array}$ & Good $0.2 \%$ & $\begin{array}{l}\text { Poor (1\% } \\
\text { of weight) }\end{array}$ & Good \\
\hline $\begin{array}{c}\text { Effect as Infiltration } \\
\text { barrier }\end{array}$ & $\begin{array}{l}\text { Extremely } \\
\text { good }\end{array}$ & Good & Poor & Good \\
\hline $\begin{array}{c}\text { Maximum service } \\
\text { temperature }\left({ }^{\circ} \mathrm{C}\right)\end{array}$ & 100 & $4-350$ & $240-800$ & $40-90$ \\
\hline Typical applications & $\begin{array}{l}\text { Walls, roofs, } \\
\text { floors, } \\
\text { perimeter, } \\
\text { basements, } \\
\text { and } \\
\text { foundations }\end{array}$ & $\begin{array}{l}\text { Cavity walls, } \\
\text { roofs, and } \\
\text { prefabricated } \\
\text { structures. }\end{array}$ & Cavities & $\begin{array}{c}\text { Ceilings, } \\
\text { hangers, } \\
\text { wrapping, carpet } \\
\text { underlay, } \\
\text { expansion joints. }\end{array}$ \\
\hline
\end{tabular}

\subsection{Cost benefit analysis and payback calculation}

The optimum insulation thickness depends on the cost benefits of each insulation material over its lifetime. For the purpose of cost benefit analysis and payback calculation, many studies have assumed that the lifetime of thermal insulation materials is 30 years [10, 22, 36, 37]. The annual energy consumption and its contribution to the annual energy saving and payback are calculated using the following equations:

$$
\begin{aligned}
\mathrm{Q}_{\mathrm{ce}} & =\left(\mathrm{Q}_{\mathrm{bc}}-\mathrm{Q}_{\mathrm{sc}}\right) / \mathrm{Q}_{\mathrm{bc}} * 100, \\
\mathrm{C}_{\mathrm{ce}} & =\left(\mathrm{Q}_{\mathrm{bc}}-\mathrm{Q}_{\mathrm{sc}}\right) * 0.05, \\
\mathrm{P}_{\mathrm{b}} & =\mathrm{C}_{\mathrm{im}} * 12 / \mathrm{C}_{\mathrm{ce}}
\end{aligned}
$$

where $\mathrm{Q}_{\mathrm{ce}}$ denotes the percentage of conserved energy, and $\mathrm{Q}_{\mathrm{bc}}$ and $\mathrm{Q}_{\mathrm{sc}}$ denote the energy consumption in the base and simulated cases 
$(\mathrm{kWh} / \mathrm{y})$, respectively. $\mathrm{C}_{\mathrm{ce}}$ denotes the cost of conserved energy in USD, and an amount of 0.05 USD denotes an electricity tariff for residential buildings in KSA (per $\mathrm{kWh}$ ). $\mathrm{P}_{\mathrm{b}}$ denotes the duration of the payback per month. $\mathrm{C}_{\mathrm{im}}$ denotes the total cost of the insulation material in USD. A total of 12 months denote the payback period.

Table 3. Main parameters used in economic analysis of the insulation material

\begin{tabular}{|c|c|}
\hline Insulation type & XPS (closed cell foam) \\
\hline Cost of insulation $\left(\$ / \mathrm{m}^{3}\right)$ & 146.7 \\
\hline Cost of electricity $(\$ / \mathrm{kWh})$ & 0.05 \\
\hline Building lifetime (y) & 30 \\
\hline \multirow{4}{*}{$\begin{array}{l}\text { Position of the insulation layer in the } \\
\text { roof }(2-14 \mathrm{~cm})\end{array}$} & 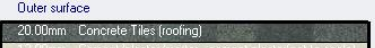 \\
\hline & $5000 \mathrm{~mm}$ Serd and gavel \\
\hline & 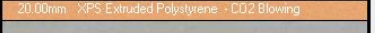 \\
\hline & Inner surface \\
\hline \multirow{4}{*}{$\begin{array}{l}\text { Position of the insulation layer in the } \\
\text { wall }(2-14 \mathrm{~cm})\end{array}$} & Oules sufface \\
\hline & \\
\hline & 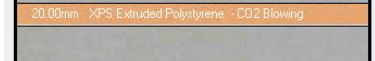 \\
\hline & Inners sufface \\
\hline
\end{tabular}

\section{Results and Discussion}

\subsection{Impact of insulation position in energy conservation and $\mathrm{CO}_{2}$ emission reduction}

Figs. 10 and 11 illustrate the effect of thermal insulation thickness on energy consumption by considering three different thermal insulation positions (on the roof only, on the walls only and on the roof and walls). Fig. 10 shows the decrease in energy consumption $\left(\mathrm{kWh} / \mathrm{m}^{2} / \mathrm{y}\right)$. Fig. 11 shows the percentage of conserved energy when the thermal insulation layers are increased in the three strategies separately. Adding thermal insulation to the entire building envelope is the ideal solution, which leads to a reduction of up to $34.98 \%$ on energy consumption. Moreover, insulating only the roof can consider as the second-best 
scenario. In addition to its relatively low cost, a maximum of $20.18 \%$ reduction in energy consumption can be achieved. The minimum reduction that can be achieved by using a maximum thickness of the thermal insulation is $8.98 \%$ when applying it on the walls only.

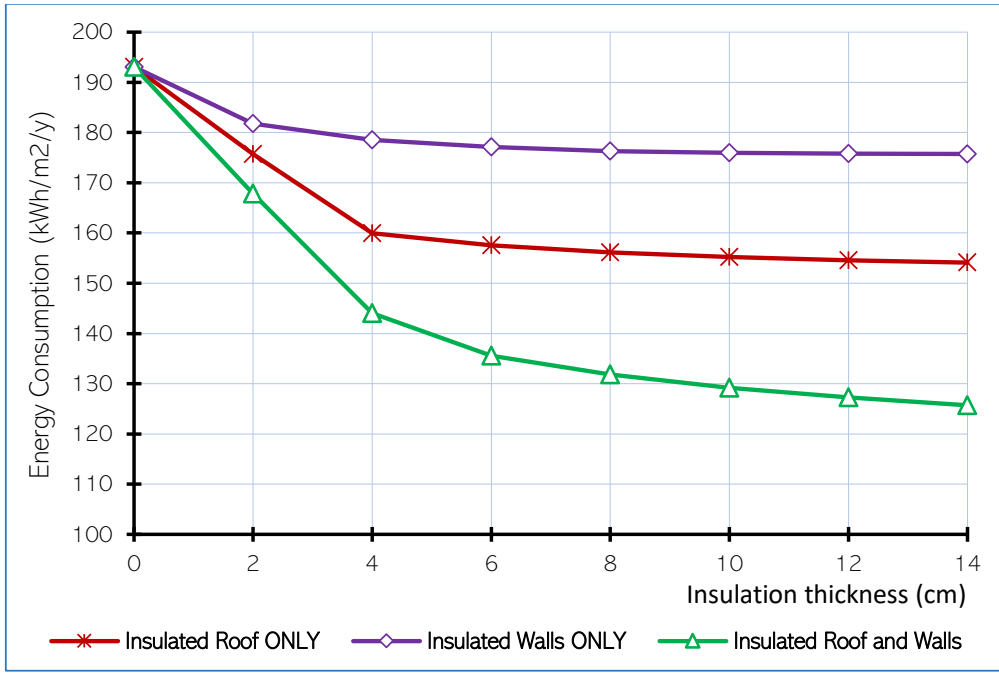

Fig. 10. Effect of insulation thickness on energy consumption considering three different thermal insulation positions.

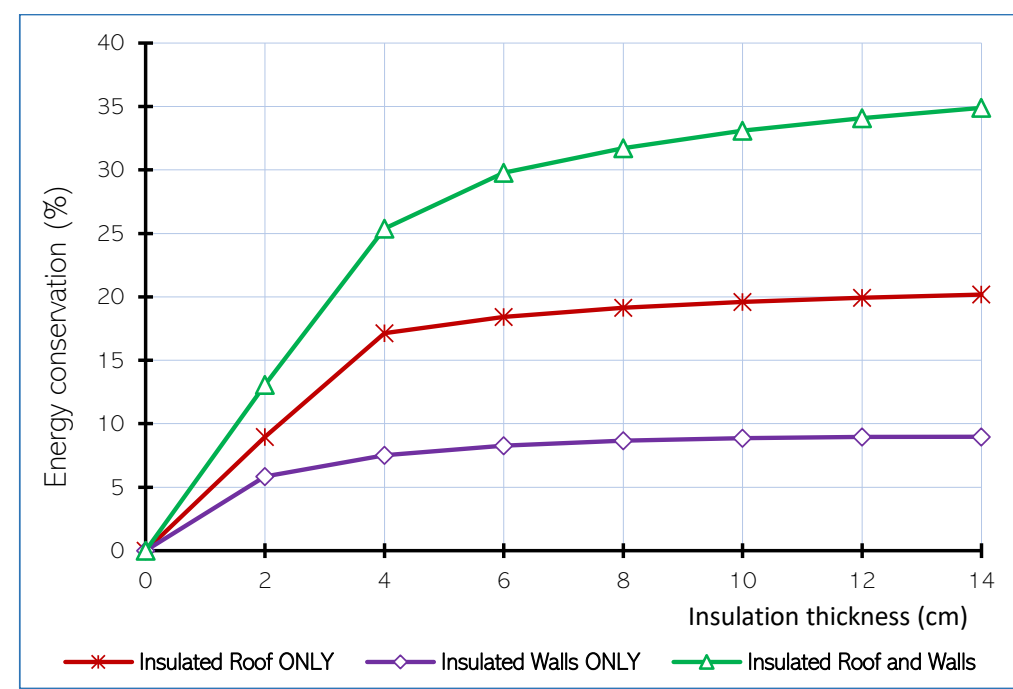

Fig. 11. Effect of insulation thickness on energy conservation. 


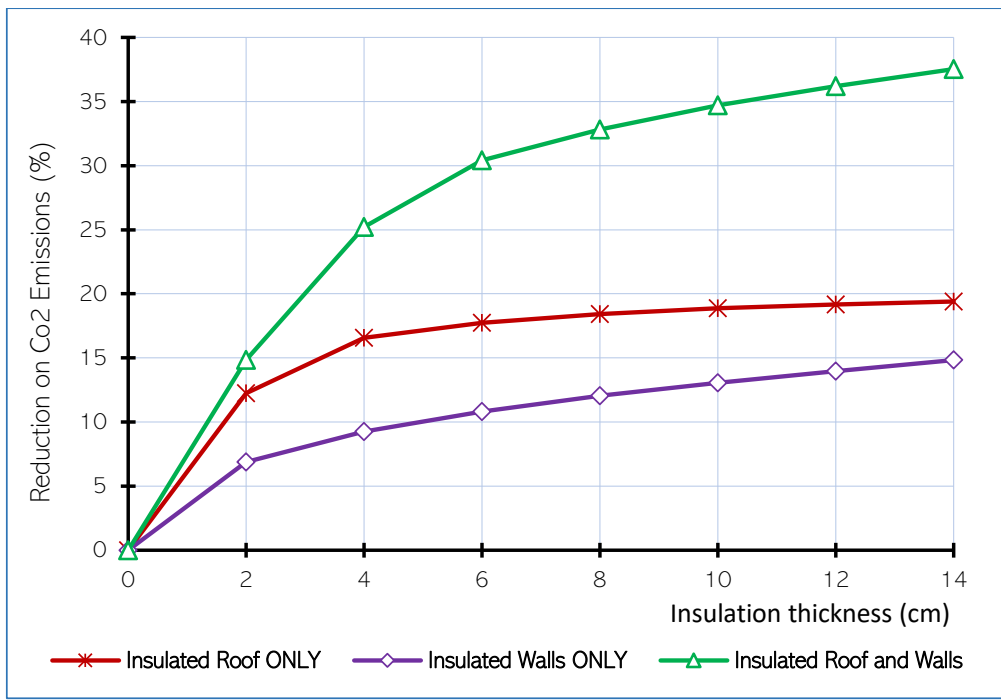

Fig. 12. Effect of insulation thickness on $\mathrm{CO}_{2}$ emission reduction.

Generally, more insulation is required on the roof than on the walls because buildings lose more energy through their roofs due to pressure gradients (hot air rising, resulting in increased pressure near the roof) and thermal gradients (air near the roof is hotter, and therefore more insulation is required to limit the increase in energy loss due to larger temperature difference across the insulation). However, roofs are more exposed to direct solar rays than the differentiation of walls orientation and the variation of solar altitude angles throughout daytime periods under the climate condition of Najran.

Results of annual $\mathrm{CO}_{2}$ emission were calculated by DesignBuilder based on the change of thermal insulation applied in varied positions are summarised in Table 4, and the percentages of their reduction are graphically presented in Fig. 12. The results show that the energy consumption and the $\mathrm{CO}_{2}$ emissions are reduced when the insulation thickness is increased. The highest emission reduction rate can be obtained by applying thermal insulation layers on the roof and walls. Compared with the $12,742.05 \mathrm{~kg}$ of $\mathrm{CO}_{2}$ emission per year, the minimum production of approximately 10,270.24, 10,852.36 and $7,960.55 \mathrm{~kg} / \mathrm{y}$ can be achieved by applying $14 \mathrm{~cm}$ of thermal insulation on the roof only, walls only and roof and walls, respectively. The maximum $\mathrm{CO}_{2}$ reduction percentages of $19.4 \%, 14.8 \%$ and $37.5 \%$ are achieved by the three strategies, respectively. 
Table 4. $\mathrm{CO}_{2}$ emission for different insulation thickness based on three proposed positions.

\begin{tabular}{|c|c|c|c|}
\hline \multirow{2}{*}{$\begin{array}{c}\text { Insulation } \\
\text { Thickness }(\mathrm{cm})\end{array}$} & \multicolumn{3}{|c|}{$\mathrm{CO}_{2}$ productions $(\mathrm{kg} / \mathrm{y})$} \\
\hline & $\begin{array}{c}\text { Insulated Roof } \\
\text { ONLY }\end{array}$ & $\begin{array}{c}\text { Insulated Walls } \\
\text { ONLY }\end{array}$ & $\begin{array}{c}\text { Insulated Roof and } \\
\text { Walls }\end{array}$ \\
\hline No Insulation & & $12,742.05$ & \\
\hline 2 & $11,181.19$ & $11,866.72$ & $10,852.36$ \\
\hline 4 & $10,632.61$ & $11,561.04$ & $9,527.75$ \\
\hline 6 & $10,481.14$ & $11,362.53$ & $8,868.44$ \\
\hline 8 & $10,393.68$ & $11,208.63$ & $8,559.54$ \\
\hline 10 & $10,338.17$ & $11,077.96$ & $8,322.40$ \\
\hline 12 & $10,299.12$ & $10,960.70$ & $8,127.85$ \\
\hline 14 & $10,270.24$ & $10,852.36$ & $7,960.55$ \\
\hline
\end{tabular}

\subsection{Optimum insulation thickness and cost benefit}

The simulated results show that as the insulation thickness increases, the energy consumption and $\mathrm{CO}_{2}$ emission reductions become evident. This condition also leads to reduced energy costs. However, insulation cost increases linearly with insulation thickness. Hence, a nonlinear relationship exists between total cost and insulation thickness. The total cost decreases with increasing insulation thickness until it reaches the optimum insulation thickness, where the total cost is at its minimum. This condition will continue to have an upward trend. Figs. 13, 14 and 15 illustrate this condition with the application of different thicknesses of extruded insulation to the three proposed positions: on the roof only, on the walls only and on the roof and walls, respectively. The results show that the optimum thermal insulation thicknesses of the three strategies are 8, 4 and $6 \mathrm{~cm}$, respectively. These figures also indicate the environmental impact and the cost savings of the three strategies at their optimum insulation thicknesses. Applying the optimum thermal insulation thickness of $6 \mathrm{~cm}$ on the roof and walls has the highest total cost savings of $23.4 \%$. Applying the optimum thickness of $8 \mathrm{~cm}$ on the roof only has the second highest total cost savings of $16.8 \%$. Finally, applying the optimum thickness of $4 \mathrm{~cm}$ on the walls only has the lowest total cost savings of approximately $4.5 \%$.

Table 5 summarises the cost benefit analysis results of the optimum thermal insulation thickness application to the three strategies of insulation layer position. Their economic and environmental impact is also explained. The results show that applying $6 \mathrm{~cm}$ of XPS insulation material on the roof and walls of residential buildings in the hot arid 
climate of KSA is the best solution amongst the rest of the alternatives because it has the highest life cycle total costs and lowest payback period of 1.8 years. Moreover, this solution leads to a $30.4 \%$ reduction on $\mathrm{CO}_{2}$ emissions from $12,742.05$ to $8,868.44 \mathrm{~kg}$ annually. The payback analysis results show that applying an optimum insulation thickness on either the roof or walls only take longer period of 3.73 and 7.14 years.

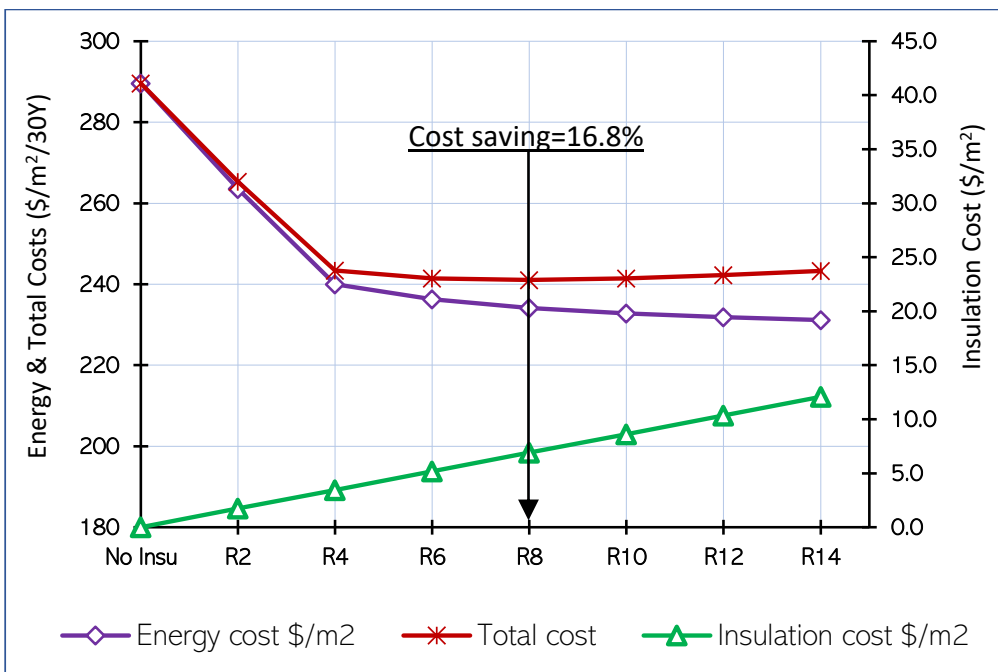

Fig. 13. Effect of insulation thickness on cost (insulated roof only).

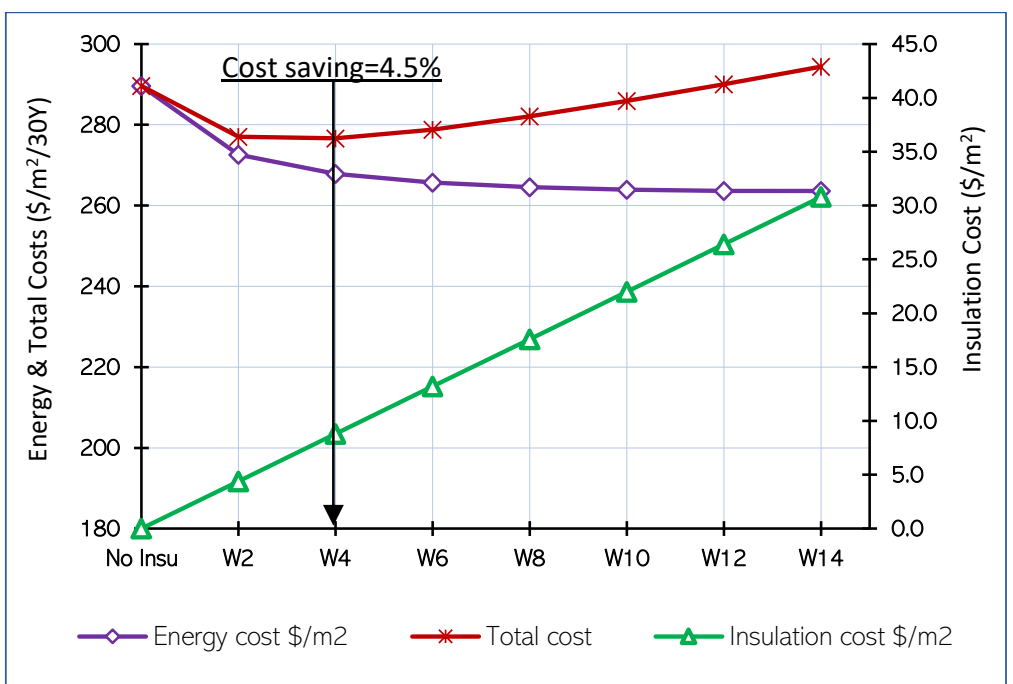

Fig. 14. Effect of insulation thickness on cost (insulated walls only). 


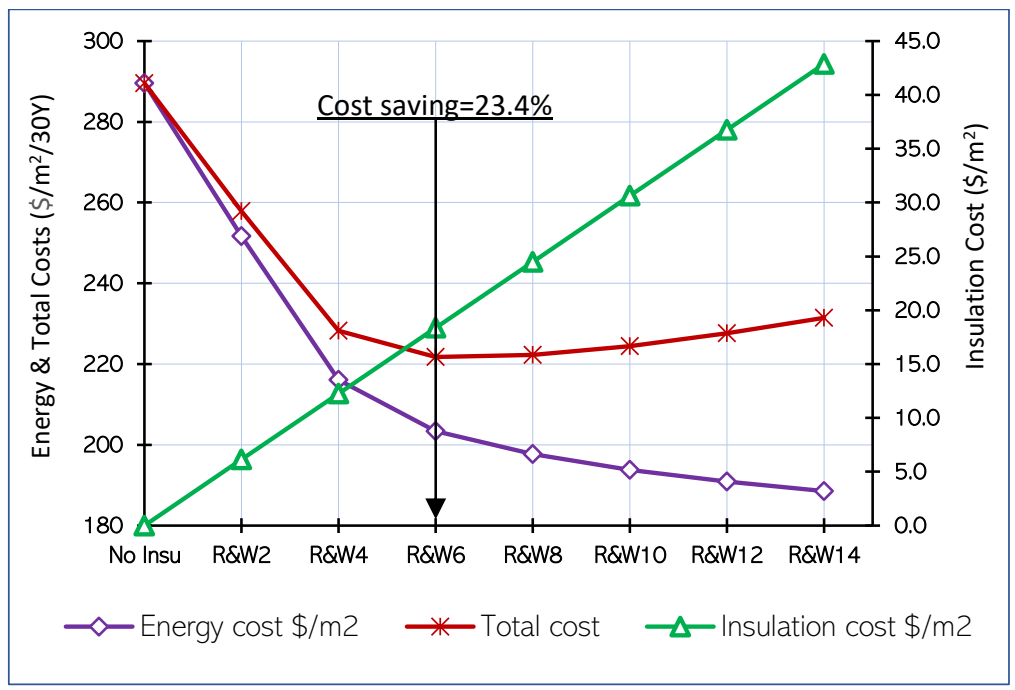

Fig. 15. Effect of insulation thickness on cost (insulated roof and walls).

Table 5. Cost effective analysis results and $\mathrm{CO}_{2}$ emissions at optimum insulation thickness

\begin{tabular}{|l|c|c|c|c|}
\hline $\begin{array}{l}\text { Alternative insulation } \\
\text { strategies }\end{array}$ & $\begin{array}{l}\text { No insulation } \\
\text { (BC) }\end{array}$ & $\begin{array}{l}\text { Insulated } \\
\text { roof only }\end{array}$ & $\begin{array}{l}\text { Insulated } \\
\text { walls only }\end{array}$ & $\begin{array}{l}\text { Insulated roof } \\
\text { and walls }\end{array}$ \\
\hline $\begin{array}{l}\text { Optimum thickness } \\
\text { (cm) }\end{array}$ & 0 & 8 & 4 & 6 \\
\hline $\begin{array}{l}\text { Energy consumption } \\
\text { kWh/m²/y }\end{array}$ & 193.07 & 156.11 & 178.57 & 135.59 \\
\hline $\begin{array}{l}\text { Percentage of } \\
\text { conserved energy (\%) }\end{array}$ & 0 & 19.14 & 7.51 & 29.77 \\
\hline $\begin{array}{l}\text { Cost of consumed } \\
\text { energy in 30 y }\end{array}$ & 68926.0 & 55731.3 & 63749.5 & 48405.6 \\
\hline $\begin{array}{l}\text { Cost of conserved } \\
\text { energy/y }\end{array}$ & 0 & 439.8 & 172.6 & 684.0 \\
\hline $\begin{array}{l}\text { Cost of optimum } \\
\text { thickness \$/m }\end{array}$ & 0 & 1642.7 & 2094.4 & 4373.7 \\
\hline Cost saving (\%) & 0 & 16.8 & 4.5 & 23.4 \\
\hline Payback period $(\mathbf{y})$ & 0 & 3.73 & 12.14 & 6.39 \\
\hline CO2 emission $(\mathbf{k g} / \mathbf{y})$ & 12742.1 & 10393.7 & 11563.7 & 8868.4 \\
\hline
\end{tabular}

\section{Conclusions}

This study used life cycle analysis to investigate the cost benefits achieved from introducing the optimum thicknesses of XPS material on building roofs and walls in a typical Saudi residential villa. The results showed that introducing the optimum thickness of selected insulation 
material reduces the annual energy consumption of buildings with $\mathrm{A} / \mathrm{C}$ systems. Although the insulation cost increased linearly with the insulation thickness, reaching the optimum insulation thickness would result in energy cost reduction such that the total cost is at its minimum. Under the hot and dry climate of Najran, the optimum insulation thicknesses of 8,4 and $6 \mathrm{~cm}$ should be applied on the roof only, walls only, and roof and walls, respectively. These three optimum thicknesses would lead to reductions of $19.14 \%, 7.51 \%$ and $29.77 \%$ on the annual energy consumption, respectively. Compared with the other two strategies, insulating only the roof exhibited the greatest life cycle savings. Specifically, the first strategy could have a life cycle savings of $\$ 55.44$ per $\mathrm{m}^{2}$, whereas the second could only have as low as $\$ 21.8$ per $\mathrm{m}^{2}$. However, the maximum life cycle savings could be achieved by applying $6 \mathrm{~cm}$ of XPS layers on the roof and walls, which could have a life cycle savings of $\$ 86.2$ per $\mathrm{m}^{2} . \mathrm{CO}_{2}$ emission reductions of approximately $18.4 \%, 9.3 \%$ and $30.4 \%$ were also achieved by applying the three optimum insulation thicknesses to three different positions, respectively. The payback period in the three optimum alternatives was $3.73,12.14$ and 6.39 years, respectively. In summary, a proper insulation material installed at its optimum thickness could not only reduce the heat transfer through building envelopes but also achieve evident economic and environmental advantages. Hence, designers and developers could use this study to introduce insulation material in building envelope components of residential buildings in countries with hot arid climates.

\section{References}

1. GAS, Statistical Yearbook, General Authority of Statistics. 2019: Riyadh, KSA.

2. GAStat, Annual Report 2018, The General Authority for Statistics. 2019: Available at: https://www.stats.gov.sa [Accessed: 07 Oct 2019].

3. EIA. Independent Statistics and Analysis: Annual Energy Outlook 2014, US Energy Information Administration, Available at: http://www.eia.gov/forecasts/aeo/er/. [Accessed: 26 Dec. 2015]. 2014.

4. ECRA, Annual Statistical Booklet for Electricity \& Seawater Desalination Industries. 2014: Electricity and Cogeneration Regulatory Authority, KSA.

5. Taleb, H.M. and S. Sharples, Developing sustainable residential buildings in Saudi Arabia: A case study. Applied Energy, 2011. 88(1): p. 383-391.

6. Ozel, M., Effect of wall orientation on the optimum insulation thickness by using a dynamic method. Applied Energy, 2011. 88(7): p. 2429-2435.

7. Yu, J., et al., Optimum insulation thickness of residential roof with respect to solar-air degree-hours in hot summer and cold winter zone of china. Energy and Buildings, 2011. 43(9): p. 2304-2313. 
8. Al-Tamimi, N., A state-of-the-art review of the sustainability and energy efficiency of buildings in Saudi Arabia. Energy Efficiency, 2017. 10(5): p. 11291141.

9. SEEC, S.E.E.C., Energy Efficiency in KSA: Annual Report 2014. 2015: Available: http://www.seec.gov.sa [Accessed: 06-Jan-2016].

10. Al-Sanea, S.A., et al., Optimum R-values of building walls under different climatic conditions in the Kingdom of Saudi Arabia. Applied Thermal Engineering, 2016. 96: p. 92-106.

11. Alsayed, M.F. and R.A. Tayeh, Life cycle cost analysis for determining optimal insulation thickness in Palestinian buildings. Journal of Building Engineering, 2019. 22: p. 101-112.

12. Yarbrough, D.W., Thermal Insulation for Energy Conservation, in Handbook of Climate Change Mitigation, W.-Y. Chen, et al., Editors. 2012, Springer US: New York, NY. p. 649-668.

13. Ucar, A. and F. Balo, Determination of the energy savings and the optimum insulation thickness in the four different insulated exterior walls. Renewable Energy, 2010. 35(1): p. 88-94.

14. Çomakl1, K. and B. Yüksel, Optimum insulation thickness of external walls for energy saving. Applied Thermal Engineering, 2003. 23(4): p. 473-479.

15. Bolattürk, A., Optimum insulation thicknesses for building walls with respect to cooling and heating degree-hours in the warmest zone of Turkey. Building and Environment, 2008. 43(6): p. 1055-1064.

16. Yu, J., et al., A study on optimum insulation thicknesses of external walls in hot summer and cold winter zone of China. Applied Energy, 2009. 86(11): p. 25202529.

17. D'Agostino, D., et al., Evaluation of the optimal thermal insulation thickness for an office building in different climates by means of the basic and modified "costoptimal" methodology. Journal of Building Engineering, 2019. 24: p. 100743.

18. Zhang, X. and F. Cheng, Comparative assessment of external and internal thermal insulation for energy conservation of intermittently air-conditioned buildings. 2019. p. 568-584.

19. Aldossary, N.A., Y. Rezgui, and A. Kwan, Domestic energy consumption patterns in a hot and humid climate: A multiple-case study analysis. Applied Energy, 2014. 114: p. 353-365.

20. Mohsen, M.S. and B.A. Akash, Some prospects of energy savings in buildings. Energy Conversion and Management, 2001. 42(11): p. 1307-1315.

21. Ucar, A. and F. Balo, Effect of fuel type on the optimum thickness of selected insulation materials for the four different climatic regions of Turkey. Applied Energy, 2009. 86(5): p. 730-736.

22. Daouas, N., Z. Hassen, and H.B. Aissia, Analytical periodic solution for the study of thermal performance and optimum insulation thickness of building walls in Tunisia. Applied Thermal Engineering, 2010. 30(4): p. 319-326.

23. Alrashed, F., Asif, M., , Trends in Residential Energy Consumption in Saudi Arabia with Particular Reference to the Eastern Province. J. sustain. dev. energy water environ. syst., 2014. 2(4): p. 376-387. 
24. Kameni Nematchoua, M., et al., A comparative study on optimum insulation thickness of walls and energy savings in equatorial and tropical climate. International Journal of Sustainable Built Environment, 2017. 6(1): p. 170-182.

25. Bektas Ekici, B., A. Aytac Gulten, and U.T. Aksoy, A study on the optimum insulation thicknesses of various types of external walls with respect to different materials, fuels and climate zones in Turkey. Applied Energy, 2012. 92: p. 211217.

26. Bolattürk, A., Determination of optimum insulation thickness for building walls with respect to various fuels and climate zones in Turkey. Applied Thermal Engineering, 2006. 26(11): p. 1301-1309.

27. KACARE, Summary Report, Solar and Meteorological Data, King Abdullah City for Atomic and Renewable Energy, The data is calculated from November 01, 2014 to May 31, 2017. 2019.

28. Khan, M., M. Asif, and E. Stach, Rooftop PV Potential in the Residential Sector of the Kingdom of Saudi Arabia. Buildings, 2017. 7(2): p. 46.

29. MOH. Ministry of Housing, Statistical Summary Report. 2020 Available at: https://sakani.housing.sa/statistics-summary [Accessed: 12 Aug. 2020]].

30. Muller, E. Development of A Test Reference Year on A Limited Data Base for Simulations on Passive Heating and Cooling in Chile. in Proceedings of IBPSA Conference: Building Simulation. 2001. Rio de Janeiro, Brazil.

31. Grote, L. and D. Wang, Architectural research methods. 2002, New York.Print in the United tastes of America: John Wiley \& Sons.

32. Software, D. User manual. 2016.

33. Mahlia, T.M.I. and A. Iqbal, Cost benefits analysis and emission reductions of optimum thickness and air gaps for selected insulation materials for building walls in Maldives. Energy, 2010. 35(5): p. 2242-2250.

34. Al-Sanea, S.A. and M.F. Zedan, Optimum insulation thickness for building walls in a hot-dry climate. International Journal of Ambient Energy, 2002. 23(3): p. 115-126.

35. Al-Homoud, D.M.S., Performance characteristics and practical applications of common building thermal insulation materials. Building and Environment, 2005. 40(3): p. 353-366.

36. Al-Sanea, S.A. and M.F. Zedan, Improving thermal performance of building walls by optimizing insulation layer distribution and thickness for same thermal mass. Applied Energy, 2011. 88(9): p. 3113-3124.

37. Krarti, M., M. Aldubyan, and E. Williams, Residential building stock model for evaluating energy retrofit programs in Saudi Arabia. Energy, 2020. 195: p. 116980. 
عنوان عزبي:

\section{تحليل التكلفة ومميزات تطبيق بدائل العزل الحراري في

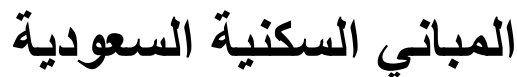

\section{ملخص عربي:}

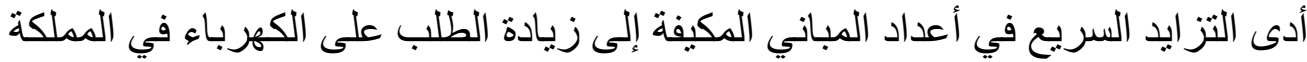

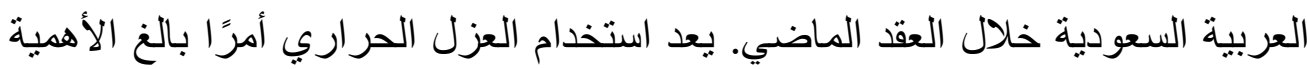

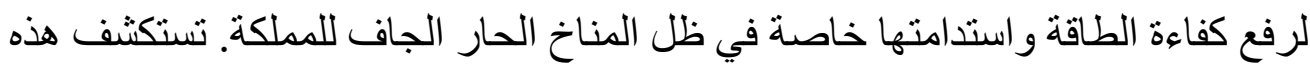

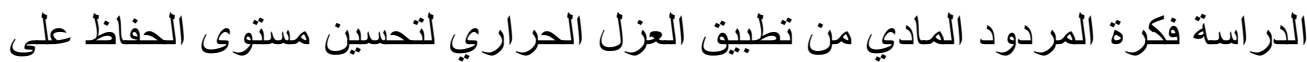

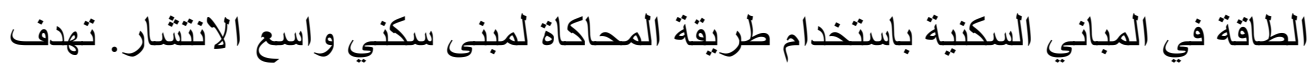

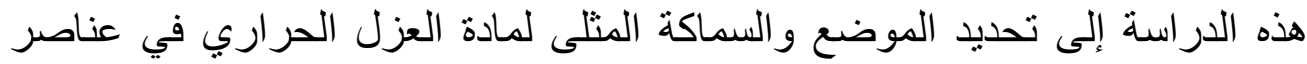

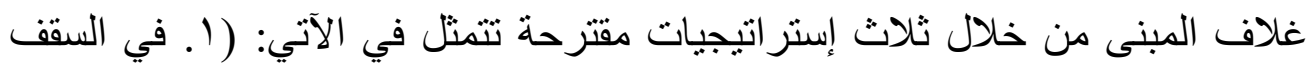

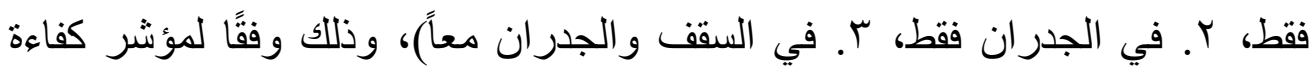

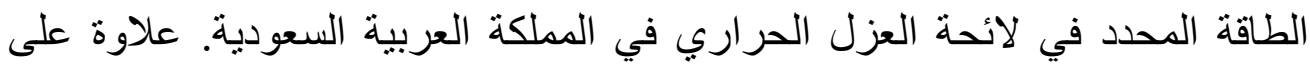
ذللك، تستخدم هذه الدراسة نموذج "تكلفة دورة الحياة" لتحديد السماكة المثلى للعازل

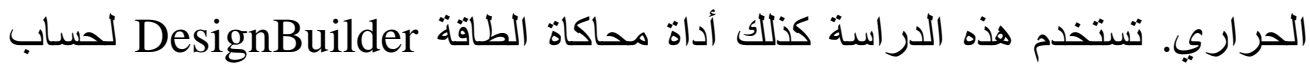

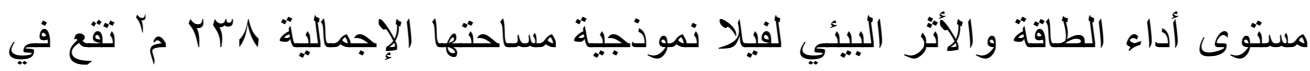

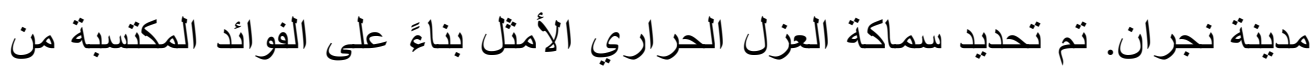

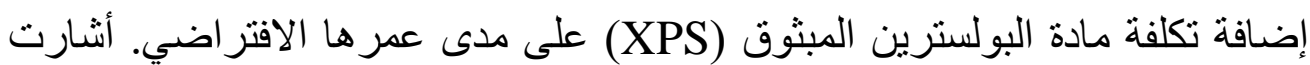

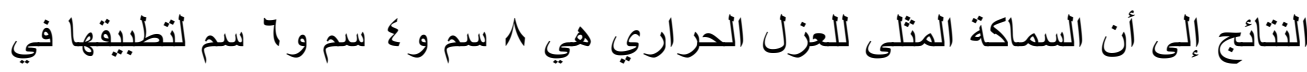
الحالات الثلاث (في السقف فقط، في الجدران فقط، في السقف والجدران الجئ معاً)

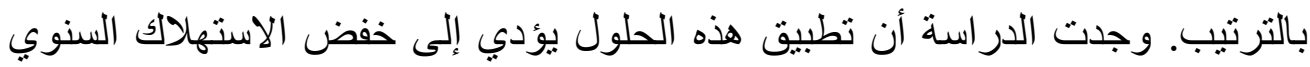

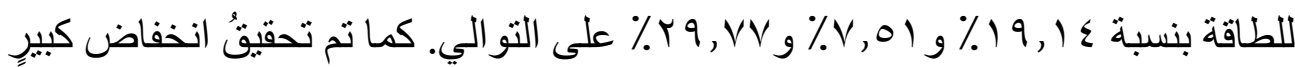

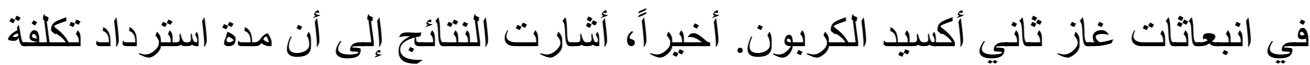

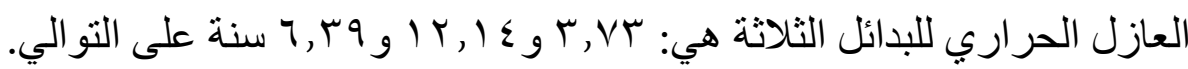

